\title{
Peroxisome Proliferator-Activated Receptor $\gamma$ Controls Ingestive Behavior, Agouti-Related Protein, and Neuropeptide Y mRNA in the Arcuate Hypothalamus
}

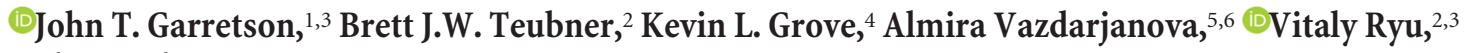 \\ and Timothy J. Bartness ${ }^{1,2,3}$ \\ ${ }^{1}$ Neuroscience Institute, ${ }^{2}$ Department of Biology, and ${ }^{3}$ Center for Obesity Reversal, Georgia State University, Atlanta, Georgia 30303, ${ }^{4}$ Oregon National \\ Primate Research Center, Oregon Health and Science University, Beaverton, Oregon 97006, ${ }^{5}$ Department of Pharmacology and Toxicology, Georgia Regents \\ University, Augusta, Georgia 30912, and ${ }^{6}$ Charlie Norwood Veterans Administration Medical Center, Augusta, Georgia 30901
}

Peroxisome proliferator-activated receptor $\gamma(\operatorname{PPAR} \gamma)$ is clinically targeted for type II diabetes treatment; however, rosiglitazone (ROSI), a PPAR $\gamma$ agonist, increases food intake and body/fat mass as side-effects. Mechanisms for these effects and the role of PPAR $\gamma$ in feeding are not understood. Therefore, we tested this role in Siberian hamsters, a model of human energy balance, and C57BL/6 mice. We tested the following: (1) how ROSI and/or GW9662 (2-chloro-5-nitro- $N$-phenylbenzamide; PPAR $\gamma$ antagonist) injected intraperitoneally or into the third ventricle (3V) affected Siberian hamster feeding behaviors; (2) whether food deprivation (FD) co-increases agouti-related protein $(A g R P)$ and PPAR $\gamma \mathrm{mRNA}$ expression in Siberian hamsters and mice; (3) whether intraperitoneally administered ROSI increases AgRP and NPY in ad libitum-fed animals; (4) whether intraperitoneally administered PPAR $\gamma$ antagonism blocks FD-induced increases in $A g R P$ and NPY; and finally, (5) whether intraperitoneally administered PPAR $\gamma$ modulation affects plasma ghrelin. Third ventricular and intraperitoneally administered ROSI increased food hoarding and intake for $7 \mathrm{~d}$, an effect attenuated by $3 \mathrm{~V}$ GW9662, and also prevented (intraperitoneal) FD-induced feeding. FD hamsters and mice increased $A g R P$ within the arcuate hypothalamic nucleus with concomitant increases in PPAR $\gamma$ exclusively within AgRP/NPY neurons. ROSI increased AgRP and NPY similarly to FD, and GW9662 prevented FD-induced increases in AgRP and NPY in both species. Neither ROSI nor GW9662 affected plasma ghrelin. Thus, we demonstrated that PPAR $\gamma$ activation is sufficient to trigger food hoarding/intake, increase $A g R P / N P Y$, and possibly is necessary for FD-induced increases in feeding and $A g R P / N P Y$. These findings provide initial evidence that FD-induced increases in AgRP/NPY may be a direct PPAR $\gamma$ dependent process that controls ingestive behaviors.

Key words: AgRP; arcuate; food hoarding; ingestive behavior; NPY; PPAR gamma

\section{Introduction}

Peroxisome proliferator-activated receptor $\gamma(\operatorname{PPAR} \gamma)$ is a nuclear receptor with known ligands (e.g., fatty acids, eicosanoids; Issemann and Green, 1990; Dreyer et al., 1993) and a role in the control of feeding (Lehrke and Lazar, 2005; Diano et al., 2011; Ryan et al., 2011). Clinically, PPAR $\gamma$ agonists thiazolidinediones [TZDs; e.g., rosiglitazone (ROSI)] increase expression of insulindependent genes in patients with type II diabetes, thereby increasing

\footnotetext{
Received May 26, 2014; revised Jan. 12, 2015; accepted Jan. 22, 2015.

Author contributions: J.T.G., B.J.W.T., V.R., and T.J.B. designed research; J.T.G., B.J.W.T., and V.R. performed research; K.L.G. and A.V. contributed unpublished reagents/analytic tools; J.T.G., B.J.W.T., V.R., and T.J.B. analyzed data; J.T.G. and T.J.B. wrote the paper.

This work was supported by National Institutes of Health Grant R01 DK078358 (T.J.B.) and National Science Foundation Grant 1258111 (A.V.). We thank Dr. Walter Wahil for providing plasmid DNA for in situ hybridization and Dr. Kristopher Bunting for instructing us on this technique. We also thank the Department of Animal Resources staff at Georgia State University for attending to the health of our research animals and Alex Thomas, Fardowsa Robow, and Dr. Cheryl Vaughan for helping with food hoarding experiments.

The authors declare no competing financial interests.

Correspondence should be addressed to Timothy J. Bartness, 24 Peachtree Center Avenue, Department of Biology, Georgia State University, Atlanta, GA 30303. E-mail: bartness@gsu.edu.

DOI:10.1523/JNEUROSCI.2129-14.2015

Copyright $\odot 2015$ the authors $\quad 0270-6474 / 15 / 354571-11 \$ 15.00 / 0$
}

insulin sensitivity (Mayerson et al., 2002), with concurrent effects including increased food intake and body/lipid mass (Wang et al., 1997; Festuccia et al., 2008). The orexigenic role of PPAR $\gamma$ is attributed to its central effects, especially in the arcuate hypothalamic nucleus (Arc; Sarruf et al., 2009). Indeed, third ventricle (3V) ROSI injection triggers $3 \mathrm{~d}$ of increased feeding by rats (Ryan et al., 2011), whereas PPAR $\gamma$ antagonism with 3V GW9662 (2-chloro-5-nitro- $N$-phenylbenzamide) attenuates food deprivation (FD)-induced feeding but not ad libitum feeding by rats (Ryan et al., 2011). These data suggest a central role of PPAR $\gamma$ in feeding, but the underlying mechanisms are unknown.

Two populations of Arc neurons have opposing effects on food intake: increases in agouti-related protein/neuropeptide $\mathrm{Y}$ (AgRP/NPY) and pro-opiomelanocortin (POMC)/cocaine and amphetamine-regulated transcript neuronal activities increase and decrease feeding, respectively (Cheung et al., 1997; Hahn et al., 1998; Krashes et al., 2011). FD increases the following: (1) AgRP/NPY mRNA expression; (2) synthesis/release of AgRP/ NPY proteins compared with fed animals; (3) AgRP/NPY neuronal firing (Brady et al., 1990; Hahn et al., 1998; Li et al., 2000); and (4) secretion of gastric ghrelin, an orexigenic hormone and en- 
dogenous agonist to its receptor (GHSR-1a) located densely on AgRP/NPY neurons. Importantly, FD or a single 3V AgRP injection markedly increases feeding by rats (Cowley et al., 1999) and mice (Ollmann et al., 1997), as well as persistent (3-6 d) increases in feeding and food hoarding by Siberian hamsters (Day and Bartness, 2004), reminiscent of 3V ROSI-induced increases in feeding duration/magnitude by rats (Ryan et al., 2011). PPAR $\gamma$ is expressed in AgRP/NPY and POMC neuronal cell lines, and agonism excites/inhibits AgRP/POMC neuronal activity (Diano et al., 2011).

Collectively, changes in PPAR $\gamma$ mRNA in AgRP/NPY neurons may reveal a novel neural response to FD. Although GABA also is released by AgRP/NPY neurons, powerfully modulates feeding, and is effected by FD (Clark et al., 1985; Wu et al., 2009), AgRP and NPY appear more responsible for persistent increases in FDinduced feeding (Krashes et al., 2013) and food hoarding compared with GABA (Teubner et al., 2012; B.J.W.T. and T.J.B., unpublished observations). Therefore, we tested whether Arc PPAR $\gamma$ agonism/antagonism affects AgRP/NPY-mediated ingestive behaviors. This was accomplished by measuring food hoarding and food intake after $3 \mathrm{~V}$ or intraperitoneally administered ROSI and/or GW9662 injections in Siberian hamsters housed in simulated-burrow caging systems, because Siberian hamsters increase food hoarding, but not food intake, after FD similarly to humans and in contrast to rats or mice (for review, see Bartness et al., 2011). Next, we tested how PPAR $\gamma$ activation affected feeding by measuring $A g R P, P P A R \gamma$, and NPY mRNA using in situ hybridization after FD and/or agonism/antagonism of PPAR $\gamma$ in hamsters and C57BL/6 mice.

\section{Materials and Methods}

\section{Animals}

Siberian hamsters. Siberian hamsters (Phodopus sungorus) were bred in our colony (lineage has been described previously; Bowers et al., 2004). One hundred twenty-two male Siberian hamsters were raised in a summer-like photoperiod (16/8 h light/dark cycle; light offset, 11:00 P.M.), weaned at $18 \mathrm{~d}$ of age, and then group housed $\left(20 \pm 2^{\circ} \mathrm{C}\right)$. At 3 months of age, hamsters $(n=77)$ were singly housed before transfer to simulated-burrow caging systems (see below). Other hamsters $(n=50)$ were tested for $A g R P, P P A R \gamma$, and NPY mRNA expression and acylated plasma ghrelin after FD, peripheral ROSI (PPAR $\gamma$ agonist) injections, or FD (48 h; see below) with peripheral GW9662 (PPAR $\gamma$ antagonist) injections.

Mice. Male C57BL/6 mice $(n=50)$ obtained from The Jackson Laboratory at 7 weeks of age were singly housed $\left(20 \pm 2^{\circ} \mathrm{C}\right)$ in a $12 \mathrm{~h} \mathrm{light/dark}$ cycle on arrival. All mice were given tap water and standard rodent chow (LabDiet Rodent Chow 5001) ad libitum, unless stated otherwise, and housed in dedicated airflow cages $(343 \times 292 \times 155 \mathrm{~mm}$; Optimice; Animal Care Systems) with corncob bedding and one cotton Nestlet (Anacare). Mice were tested for AgRP, PPAR $\gamma$, and NPY mRNA expression and acylated plasma ghrelin after FD ( $24 \mathrm{~h}$; see below), peripheral ROSI injections, or FD with peripheral GW9662 injections in an attempt to block FD-induced increased PPAR $\gamma$.

All experiments and procedures for both hamsters and mice were approved by the Georgia State University Institutional Animal Care and Use Committee and were in accordance with Public Health Service and U.S. Department of Agriculture guidelines.

\section{Simulated-burrow caging system}

Group-housed hamsters from our breeding colony were assigned to individual polypropylene shoebox cages $(290 \times 180 \times 130 \mathrm{~mm})$ in two separate cohorts (i.e., $3 \mathrm{~V}$ or intraperitoneal injections) containing Alpha-Dri Bedding (Specialty Papers) and one cotton Nestlet (Anacare), with tap water and test diet (Dustless Precision Pellets, purified $75 \mathrm{mg}$ pellets; Bio-Serv) available ad libitum. Animals were allowed to acclimate to the photoperiod and test diet for $14 \mathrm{~d}$ before foraging and hoarding training (16/8 h light/dark cycle; light offset, 9:00 P.M.). Foraging and hoarding were assessed daily using our simulated-burrow caging system as described originally (Day and Bartness, 2001; Fig. 1A). In brief, two cages were connected with a convoluted tunnel of polyvinyl chloride tubing (38.1 $\mathrm{mm}$ inner diameter and $\sim 1.52 \mathrm{~m}$ in length) to allow each hamster to move freely between the cages. The top, clear cage $(456 \times$ $234 \times 200 \mathrm{~mm}$; "foraging cage") contained tap water, a running wheel (170 mm diameter), and a hole through which food pellets were dispensed (food pellet dispenser; Med Associates). The bottom, opaque cage $(290 \times 180 \times 130 \mathrm{~mm}$; "burrow cage") was covered to simulate the darkness of a burrow and contained Alpha-Dri bedding and one cotton Nestlet. A computer running MEDPC-IV software (Med Associates) was connected to both the running wheel and food pellet dispenser of each simulated-burrow cage, which recorded wheel revolutions and systematically triggered the food pellet dispensers to deliver one food pellet into the foraging cage for every 10 wheel revolutions throughout the duration of behavioral experiments (Fig. 1A). Hamsters naturally hoard food in their burrows in the wild (Weiner, 1987), and this caging system mimics this in the laboratory. Importantly, the food pellet acquisition occurs rapidly with limited training. All whole and fractions of food pellets were recovered from each cage and hamster food pouches daily (8:00 A.M.) and then quantified as whole pellets using a precision balance set to "parts" whereby one $75 \mathrm{mg}$ food pellet $=1$ and fractions of pellets computed by the balance.

\section{Cannulae implantation surgery}

Third ventricular cannulae were implanted stereotaxically into Siberian hamsters $(n=49)$ as described previously (Teubner et al., 2012). Animals were anesthetized with 2-3\% isoflurane (Baxter Healthcare) $\mathrm{O}_{2}$ mixture, and then each animal had its head shaved and skull exposed before lowering guide cannulae (Plastics One) into the $3 \mathrm{~V}$ (skull level, 0.0 $\mathrm{mm}$ anteroposterior, $0.0 \mathrm{~mm}$ mediolateral, and $-5.5 \mathrm{~mm}$ dorsoventral). Guide cannulae were secured to the skull using cyanoacrylate ester gel and dental acrylic anchored with three $16 \mathrm{~mm}$ jeweler's screws. Removable obturators sealed openings of guide cannulae and were only briefly removed during mock $3 \mathrm{~V}$ injections (see below) and the test $3 \mathrm{~V}$ injections. Animals received subcutaneous buprenorphine $(0.2 \mathrm{mg} / \mathrm{kg}) \mathrm{im}$ mediately after surgery and were monitored for wakefulness on a warming pad to ensure proper recovery before being returned to cages. Subcutaneous buprenorphine was administered for $2 \mathrm{~d}$ after surgery for continued analgesia during recovery, and a fresh apple slice also was given to facilitate food and fluid intake. Animals were allowed a 2 week recovery period before being returned to simulated-burrow cages and given $3 \mathrm{~V}$ test injections.

\section{Foraging and hoarding}

$\operatorname{ROSI}(1.0 \mu \mathrm{g}, 1.0 \mu \mathrm{l}$; Caymen Chemical) was delivered into the $3 \mathrm{~V}$ at the onset of their dark cycle (1:00 P.M.) to test the effect of PPAR $\gamma$ manipulation on hamster food hoarding and intake as done previously for $3 \mathrm{~V}$ injection of AgRP, NPY, or both peptides (Day and Bartness, 2004; Day et al., 2005; Teubner et al., 2012) and as done previously for the effects of ROSI on food intake in laboratory rats (Ryan et al., 2011). In an effort to reduce stress-induced changes in behavior during restraint, all animals were given "mock injections" daily for $7 \mathrm{~d}$ before each test injection, wherein each animal was gently restrained and the cannulae obturators were briefly removed and then replaced. For test injections, ad libitumfed hamsters were given $1.0 \mu \mathrm{g}$ in $1.0 \mu \mathrm{l}$ of ROSI, pH 7.5 (Caymen Chemical), a mixture of $1.0 \mu \mathrm{g}$ of ROSI and $5.0 \mu \mathrm{g}$ of PPAR $\gamma$ antagonist GW9662 in $1.0 \mu \mathrm{l}, \mathrm{pH} 7.5$ (Caymen Chemical), or equal volume of vehicle (50.0\% DMSO in sterile saline, $\mathrm{pH} 7.5$ ) was infused through a guide cannula via a microinjector attached to a microsyringe with polyethylene 20 tubing and left in place for $60 \mathrm{~s}$ after injection to minimize reflux up the guide cannulae. Obturators were replaced, and animals were returned to their simulated-burrow caging systems. Hamsters were FD for $48 \mathrm{~h}$ and then administered $5.0 \mu \mathrm{g}$ of GW9662 in $1.0 \mu \mathrm{l}$ or equal volume of vehicle during refeeding. Food hoarding and intake, as well as wheel revolutions, were then assessed daily for $7 \mathrm{~d}$, with a $10 \mathrm{~d}$ washout period. 
A

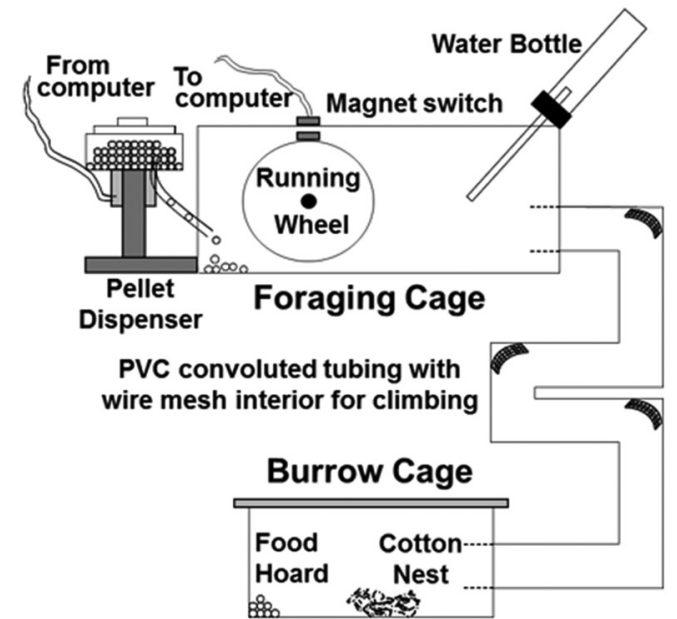

C Cumulative Food Intake

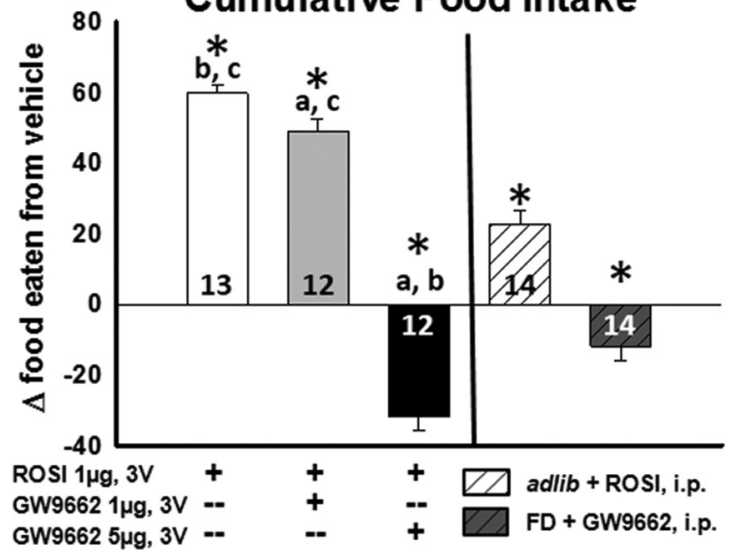

B Cumulative Food Hoard

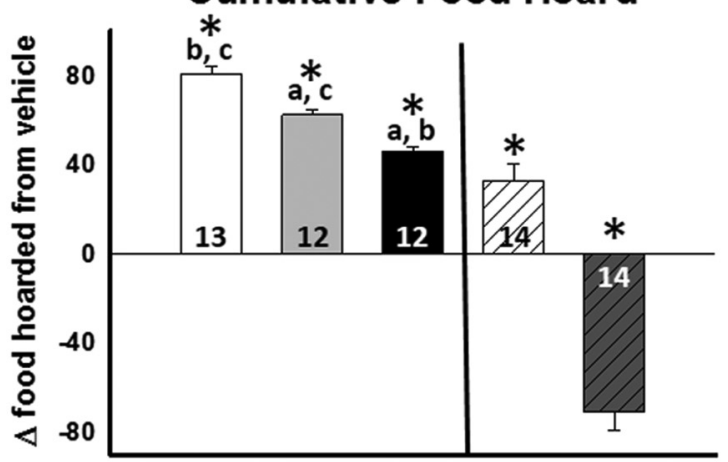

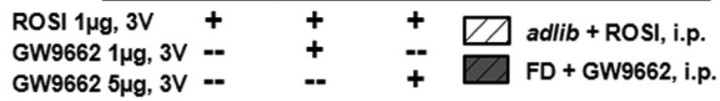

D Cumulative Wheel Revolutions

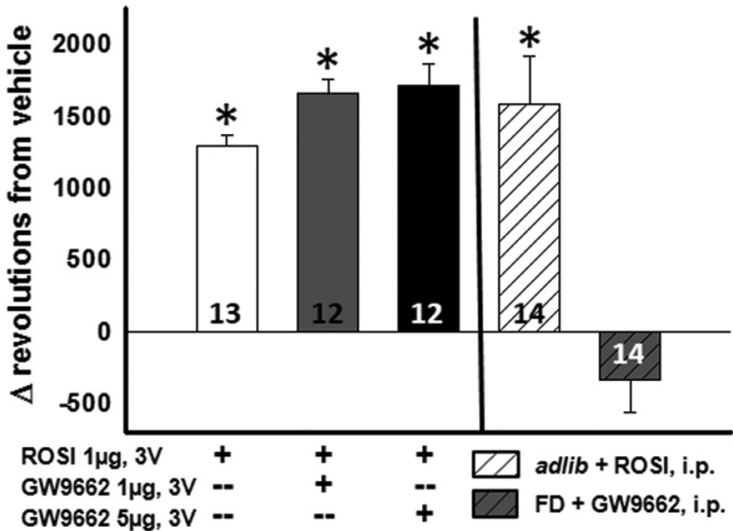

Figure 1. PPAR $\gamma$ controls feeding in Siberian hamsters. $A$, Drawing of simulated-burrow caging system. $\boldsymbol{B}-\boldsymbol{D}$, Change of cumulative food hoard $(\boldsymbol{B})$, intake $(\boldsymbol{C})$, and wheel revolutions $(\boldsymbol{D})$ from vehicle across the $7 \mathrm{~d}$ postinjection period after $3 \mathrm{~V}$ ROSI or ROSI plus GW9662 mixture injections and intraperitoneal injections of ROSI for ad libitum-fed or GW9662 for $48 \mathrm{~h}$ food-deprived hamsters ( $n$ per group noted at the base of each bar). Solid vertical line separates $3 \mathrm{~V}$ (left) from intraperitoneal (right) PPAR $\gamma$ manipulations for clarity of comparison. ${ }^{*} p<0.05$, different from vehicle injection. Bars for $3 \mathrm{~V}$ injections are lettered a $-c$ (left to right), and letters indicate significant differences from other treatments $(p<0.05)$. Error bars denote SEM. PVC, Polyvinyl chloride.

\section{Central and behavioral effects of FD and/or peripheral}

ROSI/GW9662 injections

Hamsters and mice were either FD or fed ad libitum and then killed to test whether FD naturally affects Arc $A g R P$ and $P P A R \gamma$ expression. In another cohort of animals, we gave intraperitoneal injections of ROSI (6 $\mathrm{mg} / \mathrm{kg}, \mathrm{pH} 7.5$ ) or vehicle (4.0\% DMSO in sterile saline, $\mathrm{pH} 7.5)$ at 0,6 , and $12 \mathrm{~h}$, and then we killed the hamsters and mice $24 \mathrm{~h}$ after the first injection (Yi et al., 2008) to test whether ROSI is sufficient to induce $A g R P$ and NPY mRNA. In an attempt to block FD-induced increases in brain PPAR $\gamma, A g R P$, and NPY mRNA, GW9662 (4 mg/kg, pH 7.5) or vehicle (50.0\% DMSO in sterile saline, $\mathrm{pH} 7.5)$ were injected intraperitoneally to hamsters and mice FD for different durations. Hamsters were FD for $48 \mathrm{~h}$ because FD lengths between 32 and $48 \mathrm{~h}$ produce maximum FD-induced increases in food hoarding (T.J.B. and D. E. Day, unpublished observations). For hamster PPAR $\gamma$ receptor blockade, hamsters were injected intraperitoneally with GW9662 at $0,12,24$, and $36 \mathrm{~h}$ and then killed at $48 \mathrm{~h}$ after the first injection. Mice do not tolerate FD lengths of the duration used in hamsters well (Jensen et al., 2013); therefore, mice were FD for $24 \mathrm{~h}$ and injected intraperitoneally with GW9662 at 0 and $12 \mathrm{~h}$ and then killed at $24 \mathrm{~h}$ after the first injection. Injection times, doses, and terminal time points were modeled according to the study by Yi et al. (2008) in which mice were used. Whole brains from hamsters and mice were collected, and the Arc was examined using fluorescent in situ hybridization.

To test the behavioral effects of peripheral PPAR $\gamma$ manipulation and compare these data to $3 \mathrm{~V}$ administration/in situ hybridization studies above, a separate cohort of hamsters $(n=28)$ acclimated to simulatedburrow caging systems were either fed ad libitum and administered ROSI
[6 $\mathrm{mg} / \mathrm{kg}$, i.p.; injection times as above with last injection at the onset of the dark cycle (1:00 P.M.)] or FD (48 h) and administered GW9662 (4 $\mathrm{mg} / \mathrm{kg}$, i.p.) starting at the onset of FD and the dark cycle (1:00 P.M.) and continuing every $12 \mathrm{~h}$ until $7 \mathrm{~d}$ after refeeding.

Blood collection/acylated ghrelin ELISAs

Immediately before the hamsters and mice used for fluorescent in situ hybridization were killed, blood was collected for ELISA (Mouse/Rat Acylated Ghrelin ELISA; Caymen Chemical) from hamsters (retroorbital sinus) and mice (atrial puncture) as specified exactly according to the instructions of the manufacturer to assess whether intraperitoneal PPAR $\gamma$ manipulation affects plasma acylated ghrelin that in turn could indirectly stimulate $\operatorname{Arc} A g R P / N P Y$ expression and trigger the changes in $\operatorname{PPAR} \gamma$ and ingestive behavior. Briefly, blood was collected with heparinized Natelson tubes/syringes, gently transferred to vials containing EDTA, and then put on ice until all samples were collected. Blood transfer buffer $(1.2 \% \mathrm{NaOH}, 2 \mathrm{~mm} p$-hydroxymercuribenzoic acid, $500 \mathrm{~mm}$ $\mathrm{NaCl}$, and $25 \mathrm{~mm}$ EDTA dissolved in deionized water) was added to whole blood 1:1 and then centrifuged at $5000 \mathrm{rpm}$ and $4^{\circ} \mathrm{C}$ for $10 \mathrm{~min}$. Supernatant was removed, immediately acidified with $100 \mu$ of $1 \mathrm{~N} \mathrm{HCl}$, then spun again at $5000 \mathrm{rpm}$ and $4^{\circ} \mathrm{C}$ for $10 \mathrm{~min}$, and stored at $-80^{\circ} \mathrm{C}$ until assay. All samples were assayed in duplicate without additional dilution, and absorbance was quantified at $414 \mathrm{~nm}$ using a spectrophotometric plate reader. All sample concentrations were calculated by the software according to a four-parameter acylated ghrelin standard serially diluted from the kit. 
Tissue preparation for fluorescent in situ hybridization

Animals were given an overdose of Fatal Plus $(300 \mathrm{mg} / \mathrm{kg}$, i.p.; Vortech Pharmaceuticals) and then transcardially perfused first with $75 \mathrm{ml}$ of heparinized $0.9 \% \mathrm{NaCl}$ in $\mathrm{RNase}$ free $0.01 \%$ diethylpyrocarbonate (DEPC)-treated $\mathrm{dH}_{2} \mathrm{O}$ and then with $150 \mathrm{ml}$ of $4.0 \%$ paraformaldehyde in $0.1 \mathrm{M}$ PBS made with sterile filtered $\mathrm{dH}_{2} \mathrm{O}$. Brains were removed, postfixed in $4.0 \%$ paraformaldehyde in $0.1 \mathrm{M}$ PBS for $4 \mathrm{~h}$, and then allowed to sink in autoclaved sterile $0.01 \%$ DEPC-treated $30.0 \%$ sucrose overnight at $4^{\circ} \mathrm{C}$. Brains were sectioned rostral to caudal on a freezing microtome at $20 \mu \mathrm{m}$ in series over four slides for each brain to contain all sections of Arc. All slides were frozen at $-80^{\circ} \mathrm{C}$ until use to reduce mRNA degradation before analysis (Andreasson et al., 2013).

\section{Fluorescent in situ hybridization for AgRP, PPAR $\gamma$, and NPY $m R N A$}

Double-fluorescent in situ hybridization was performed to analyze both $A g R P$ and PPAR $\gamma$ mRNA and modified slightly from previous protocols used for rat brains (Vazdarjanova et al., 2002). Single-stranded antisense mRNA fragments for $A g R P$ (created by K.L.G.) and PPAR (generous gift from Dr. Walter Wahil, University of Lausanne, Lausanne, Switzerland) were reverse transcribed from plasmid DNA and labeled with digoxigenin (DIG RNA Labeling Mix; Roche Applied Sciences) and FITC (FITC RNA Labeling Mix; Roche Applied Sciences), respectively. Labeled riboprobes for mouse tissue were synthesized from mouse AgRP and PPAR $\gamma$ DNA, whereas riboprobes for hamster tissue were synthesized from rat AgRP and PPAR $\gamma$ DNA because of nonspecific labeling of mouse riboprobes in hamster tissue (J.T.G, V.R., and T.J.B., unpublished observations). NPY riboprobes were synthesized from hamster (provided by S. Chua, Columbia University, New York, NY), labeled with digoxigenin, and used with both hamster and mouse tissue.

Frozen slide-mounted sections were removed from $-80^{\circ} \mathrm{C}$ and allowed to reach room temperature immediately before use. Sections were submerged in $2 \times$ SSC, acetylated with $0.1 \mathrm{M}$ triethanolamine $/ 0.25 \%$ acetic anhydride solution in $0.01 \%$ DEPC-treated $\mathrm{dH}_{2} \mathrm{O}$, and then fixed in acetone/methanol (1:1). The sections were then prehybridized for 30 $\mathrm{min}$ at room temperature in hybridization buffer, followed by hybridization with antisense riboprobes (150 ng/slide) for AgRP and PPAR $\gamma$ in a humid chamber for $16 \mathrm{~h}$ at $58^{\circ} \mathrm{C}$. We found that all our riboprobes hybridize specifically, as validated by the absence of fluorescence with the no probe/sense probe controls. Slides were removed from humid chambers and submerged into RNase A $(20 \mu \mathrm{g} / \mathrm{ml})$ in $2 \times \mathrm{SSC}$ at $37^{\circ} \mathrm{C}$ to degrade unbound RNA, then transferred into descending SSC concentrations to $0.5 \times \mathrm{SSC}$ for $30 \mathrm{~min}$ at $58^{\circ} \mathrm{C}$, and finally quenched endogenous peroxidase activity with $1.0 \% \mathrm{H}_{2} \mathrm{O}_{2}$ all to reduce nonspecific visualization of unbound riboprobes. Bound and labeled antisense mRNA probes were then visualized in series first by permeabilization with $0.05 \%$ Tween 20 in $0.1 \mathrm{M}$ Tris- $\mathrm{HCl}$, blocked with $10.0 \%$ normal sheep serum (NShS) in 5.0\% casein in $0.1 \mathrm{~m}$ Tris-buffered saline (TBS), next incubated with sheep anti-digoxigenin FAB fragments (1:250; Roche Applied Sciences) in 10.0\% NShS and 5.0\% casein in TBS, amplified via tyramide signal amplification (TSA; 1:200; TSA Plus Cyanine 3 Kit; PerkinElmer Life and Analytical Sciences), and then followed by a second quenching of residual FAB fragment-introduced peroxidase activity with $3.0 \% \mathrm{H}_{2} \mathrm{O}_{2}$ in $0.1 \mathrm{M}$ TBS. We then visualized the bound FITClabeled probes with sheep anti-FITC FAB fragments (1:250; Roche Applied Sciences) that were amplified via TSA (1:200; TSA Plus Fluorescein; PerkinElmer Life and Analytical Sciences). Slides were coverslipped with Prolong antifade fluorescent medium (Invitrogen) and stored at room temperature until image capture. Treatments compared with one another (e.g., ad libitum vs FD, ROSI vs vehicle, and GW9662 vs vehicle) were always included together in each in situ procedure to reduce variability between separate assays.

In follow-up experiments, single NPY in situ hybridization using DIGlabeled NPY antisense riboprobes was performed as above from a separate cohort of mice and hamsters to test whether PPAR $\gamma$ modulation specifically affects $A g R P$ mRNA or more generally affects orexigenic mRNA from AgRP/NPY neurons.

\section{Quantification of fluorescent labeling}

Fluorescent quantification within the Arc and median eminence (ME) was completed by experimenters blind to treatment conditions. Total cells expressing NPY, AgRP, PPAR $\gamma$, or colocalized with both $A g R P$ and $P P A R \gamma$ were counted and collapsed across all levels of the Arc and ME according to Paxinos and Franklin (2007). A mouse brain atlas was used for both species (Lein et al., 2007; Paxinos and Franklin, 2007) because it best matches with most Siberian hamster brain areas, doing so much better than the Syrian hamster brain atlas, and because no Siberian hamster brain atlas is available. Area of fluorescence and relative fluorescence intensity (RFI) for each mRNA probe was quantified using NIH ImageJ software (Schneider et al., 2012) according to methods used previously to characterize immunofluorescence in the brain (van der Laan et al., 2005). Background was normalized across sections to ensure that fluorescent intensity was measured equally across treatments. Intensity measures were then captured throughout the Arc and ME separately and averaged across each animal for $A g R P$ and then PPAR $\gamma$ to be compared across treatments as mean fluorescent intensity among groups. Colocalized or PPAR $\gamma$ mRNA only expressing cells were then visually traced, and RFI measures of PPAR $\gamma$ expression were taken to identify how PPAR $\gamma$ gene expression differed within or outside AgRP/NPY neurons.

\section{Statistical analysis}

Behavioral effects of central and peripheral ROSI and/or GW9662. The effects of central ROSI and/or GW9662 on hoarding, intake, and wheel revolutions were analyzed first with one-way ANOVA and then using multiple between-subjects Student's $t$ tests with Bonferroni's correction comparing cumulative scores over the $7 \mathrm{~d}$ test period (because there was no main effect of time) to test whether central ROSI and/or the ROSI and GW9662-induced behaviors different from vehicle controls. Cumulative food hoarding, intake, and wheel revolutions over $7 \mathrm{~d}$ from intraperitoneally injected animals were compared between treatment conditions using preplanned multiple Student's $t$ tests between groups.

Treatment effects on AgRP, PPAR $\gamma$, and NPY mRNA, and acylated ghrelin. The mean number of NPY-, AgRP-, and/or PPAR $\gamma$-positive neurons, mean expression area, and mean RFI were compared between treatment groups using separate Student's $t$ tests to examine the effects of (1) FD, (2) ROSI in ad libitum-fed animals, and (3) GW9662 to block FDinduced increases in acylated ghrelin, NPY, AgRP, and/or PPAR $\gamma$ gene expression for both hamsters and mice. All statistical tests were considered significant if $p<0.05$.

\section{Results}

\section{Central ROSI increases food hoarding and intake in hamsters and is attenuated by GW9662}

$3 \mathrm{~V}$ infusion of ROSI or ROSI plus GW9662 (1.0 and $5.0 \mu \mathrm{g})$ induced a significant main effect on food hoarding $\left(F_{(3,45)}=\right.$ 28.786, $p<0.01$; Fig. $1 B)$, intake $\left(F_{(3,45)}=32.828, p<0.01\right.$; Fig. $1 C)$, and wheel revolutions $\left(F_{(3,45)}=10.308, p<0.01\right.$; Fig. $\left.1 D\right)$. $3 \mathrm{~V}$ infusion of ROSI increased hamster food hoarding when compared with vehicle-injected animals $\left(t_{(23)}=5.021, p<0.01\right)$, unlike preliminary experiments with $3 \mathrm{~V}$ ROSI in which this effect was specific to food hoarding with nonsignificantly increased food intake; food intake $\left(t_{(23)}=4.602, p<0.01\right)$ and wheel revolutions $\left(t_{(23)}=2.602, p<0.05\right)$ also were significantly increased, suggesting that PPAR $\gamma$ in this species may be involved with food hoarding (Fig. 1B), intake (Fig. 1C), and foraging behaviors (Fig. 1D). 3V ROSI/GW9662 mixtures at 1.0 and $5.0 \mu \mathrm{g}$ of GW9662 both increased food hoarding $\left(t_{(22)}=4.126, p<0.01\right.$; $\left.t_{(22)}=2.127, p<0.05\right)$, whereas $1.0 \mu \mathrm{g}$ of GW9662 increased $\left(_{(22)}=3.384, p<0.01\right)$ and $5.0 \mu \mathrm{g}$ decreased $\left(t_{(22)}=-2.413\right.$, $p<0.05)$ food intake compared with vehicle; however, each dose specifically attenuated ROSI-induced increases in food hoarding $\left(1.0 \mu \mathrm{g}, t_{(23)}=-2.464, p<0.05 ; 5.0 \mu \mathrm{g}, t_{(23)}=-3.297, p<\right.$ $0.01)$ and food intake $\left(1.0 \mu \mathrm{g}, t_{(23)}=-2.627, p<0.05 ; 5.0 \mu \mathrm{g}\right.$, $\left.t_{(23)}=-7.662, p<0.01\right)$ but not wheel revolutions ( $p$ values $>$ $0.05)$. Thus, GW9662 blocked the effects of ROSI on food hoard- 

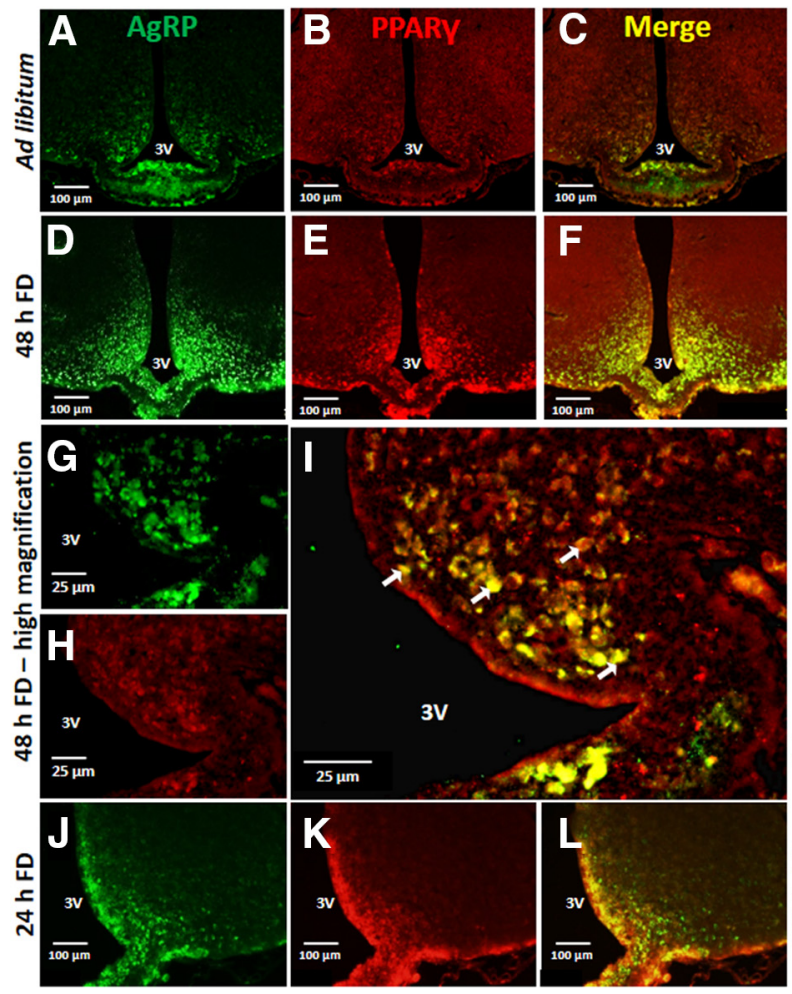

ARC Gene Expression in Hamsters

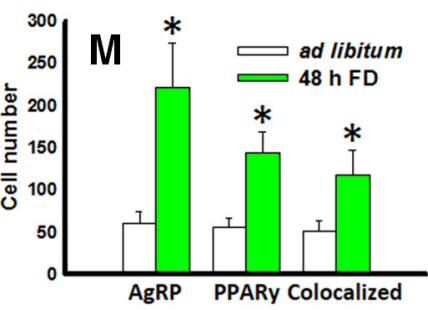

Arc Gene Expression
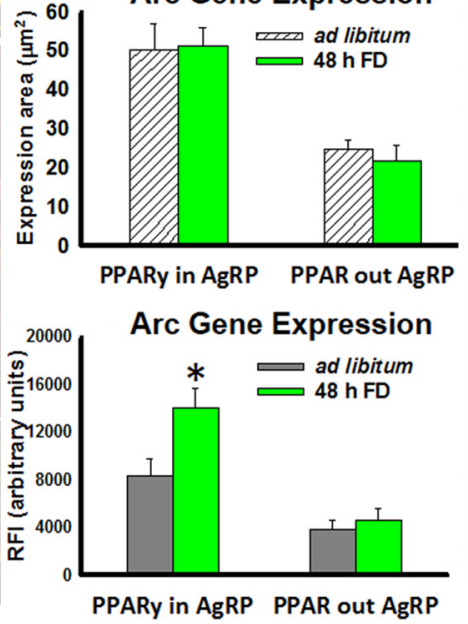

ARC Gene Expression in Mice

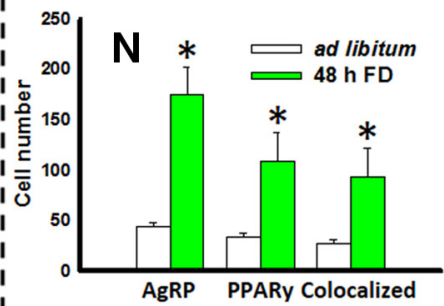

Arc Gene Expression

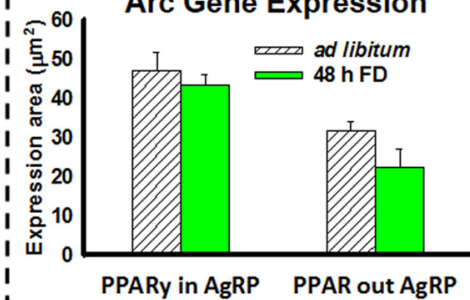

Arc Gene Expression

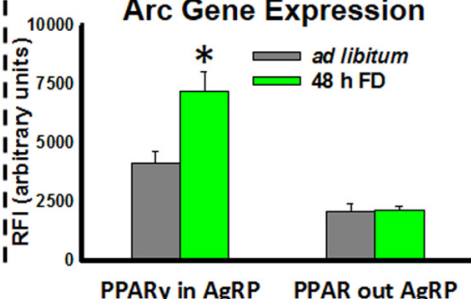

Figure 2. FD co-increases AgRP and PPAR $\gamma$ in the Arc. Double-fluorescent in situ hybridization for AgRP (green), PPAR $\gamma($ red), and merged representative images of ad libitum-fed $(\boldsymbol{A}-\boldsymbol{C})$ and $48 \mathrm{~h}$ FD (D-F) Siberian hamsters. G-I, High-magnification images from $48 \mathrm{~h}$ FD Siberian hamsters. White arrows point to some, but not all, colocalized cells. $J-L$, Double-fluorescent in situ hybridization of $24 \mathrm{~h} \mathrm{FD} \mathrm{C57BL/6} \mathrm{mice} \mathrm{for} \mathrm{AgRP} \mathrm{(green)} \mathrm{and} \mathrm{PPAR} \gamma$ (red). M, Quantification of AgRP and PPAR $\gamma$ expression from hamster brains. Top, Average number of cells expressing AgRP, PPAR $\gamma$, or colocalized with both in ad libitum-fed versus $48 \mathrm{~h} \mathrm{FD}$. Middle, Area of expression of PPAR $\gamma$ within and outside of AgRP/NPY neurons in the Arc. Bottom, RFI of PPAR $\gamma$ within and outside of AgRP/NPY neurons in the Arc. $N$, Quantification of Arc AgRP and PPAR $\gamma$ expression from C57BL/6 mouse brains. AgRP and PPAR $\gamma$ expression represented as average number of cells (top), area of expression (middle), and RFI (bottom). ${ }^{*} p<0.05$, different from the ad libitum feeding condition. Vertical dotted line separates hamster $(\boldsymbol{M}, n=10)$ from mice $(\boldsymbol{N}, n=10)$ quantification. Error bars denote SEM.

ing and intake specifically without affecting overall activity. A single 3V injection of GW9662, in contrast to rats (Ryan et al., 2011) and chronic peripheral GW9662 in hamsters (below), was not sufficient to block FD-induced increases in food hoarding or intake ( $p$ values $>0.05$; data not shown) by hamsters.

Peripheral ROSI and GW9662 control ad libitum and FDinduced hamster food hoarding and intake

Similar to 3V infusion of ROSI and GW9662, intraperitoneally administered ROSI increased food hoarding $\left(t_{(26)}=3.533, p<\right.$ 0.01 ; Fig. $1 B)$ and food intake $\left(t_{(26)}=4.003, p<0.01\right.$; Fig. $\left.1 C\right)$ and increased wheel revolutions $\left(t_{(26)}=2.064, p<0.05\right.$; Fig. $\left.1 D\right)$. Chronic intraperitoneal GW9662 markedly attenuated FDinduced food hoarding $\left(t_{(26)}=-6.855, p<0.01\right.$; Fig. $\left.1 B\right)$ and food intake $\left(t_{(26)}=-2.288, p<0.05\right.$; Fig. 1C) but did not affect wheel revolutions $(p>0.05$; Fig. $1 D)$, suggesting that GW9662induced decreases in ingestive behavior was not caused by a general malaise, because animals with malaise do not show increases in movement-associated behaviors but instead show decreases.

\section{FD co-increases $A g R P$ and $P P A R \gamma$ mRNA in hamsters} and mice

Detectable cells expressing single $A g R P, P P A R \gamma$, or colocalized $A g R P$ plus $P P A R \gamma$ were each more numerous in FD hamsters (48 $\mathrm{h} ; t_{(8)}=2.948, p<0.05 ; t_{(8)}=3.387, p<0.01 ; t_{(8)}=2.499, p<$ 0.05 ; Fig. $2 M)$ and mice $\left(24 \mathrm{~h} ; t_{(8)}=4.711, p<0.01 ; t_{(8)}=2.595\right.$, $p<0.05 ; t_{(8)}=2.316, p<0.05$; Fig. $\left.2 N\right)$ compared with their fed counterparts. In addition, increased PPAR $\gamma$ mRNA RFI was spe- cific to AgRP/NPY neurons in hamsters $\left(t_{(8)}=6.432, p<0.01\right.$ Fig. $2 M)$ and mice $\left(t_{(8)}=3.212, p<0.05\right.$; Fig. $\left.2 N\right)$ but not in PPAR $\gamma$ cells negative for AgRP mRNA in either species ( $p$ values $>0.05$; Fig. 2). FD-induced increases in AgRP mRNA, but not $P P A R \gamma$ mRNA, were observed in the ME of hamsters (data not shown).

Peripheral ROSI increases Arc NPY, AgRP, PPAR $\gamma$, and $A g R P$ plus PPAR $\gamma$ mRNA in hamsters and mice but does not affect plasma ghrelin

Peripheral ROSI injections increased the number of detectable cells with $A g R P, P P A R \gamma$, and colocalized $A g R P$ plus $P P A R \gamma$ mRNA in both hamsters $\left(t_{(8)}=2.712, p<0.05 ; t_{(8)}=2.435, p<\right.$ $0.05 ; t_{(8)}=2.544, p<0.05$; Fig. $\left.3 G\right)$ and mice $\left(t_{(8)}=2.919, p<\right.$ $0.05 ; t_{(8)}=2.539, p<0.05 ; t_{(8)}=2.429, p<0.05$; Fig. $\left.3 H\right)$ compared with vehicle. In addition, $P P A R \gamma$ mRNA expression area was larger within AgRP/NPY neurons in both hamsters $\left(t_{(8)}=2.436, p<0.05\right.$; Fig. $\left.3 G\right)$ and mice $\left(t_{(8)}=2.656, p<0.05\right.$; Fig. $3 H)$. ROSI also increased $A g R P$ expression area in mice $\left(t_{(8)}=2.835, p<0.05\right.$; Fig. $\left.3 H\right)$ and RFI in both hamsters $\left(t_{(8)}=\right.$ 2.392, $p<0.05$; Fig. $3 G)$ and mice $\left(t_{(8)}=2.534, p<0.05\right.$; Fig. $3 H)$. The number of cells expressing PPAR $\gamma$ after FD versus peripheral ROSI injection was not different, suggesting that ROSIinduced Arc changes are reminiscent of the natural stimulus of FD (compare with above; Figs. 2, 3). In addition, ROSI increased the number of NPY-expressing cells in mice $\left(t_{(8)}=-2.372, p<\right.$ 0.05 ; see Fig. $5 J)$, but only trends of this pattern were evident in 

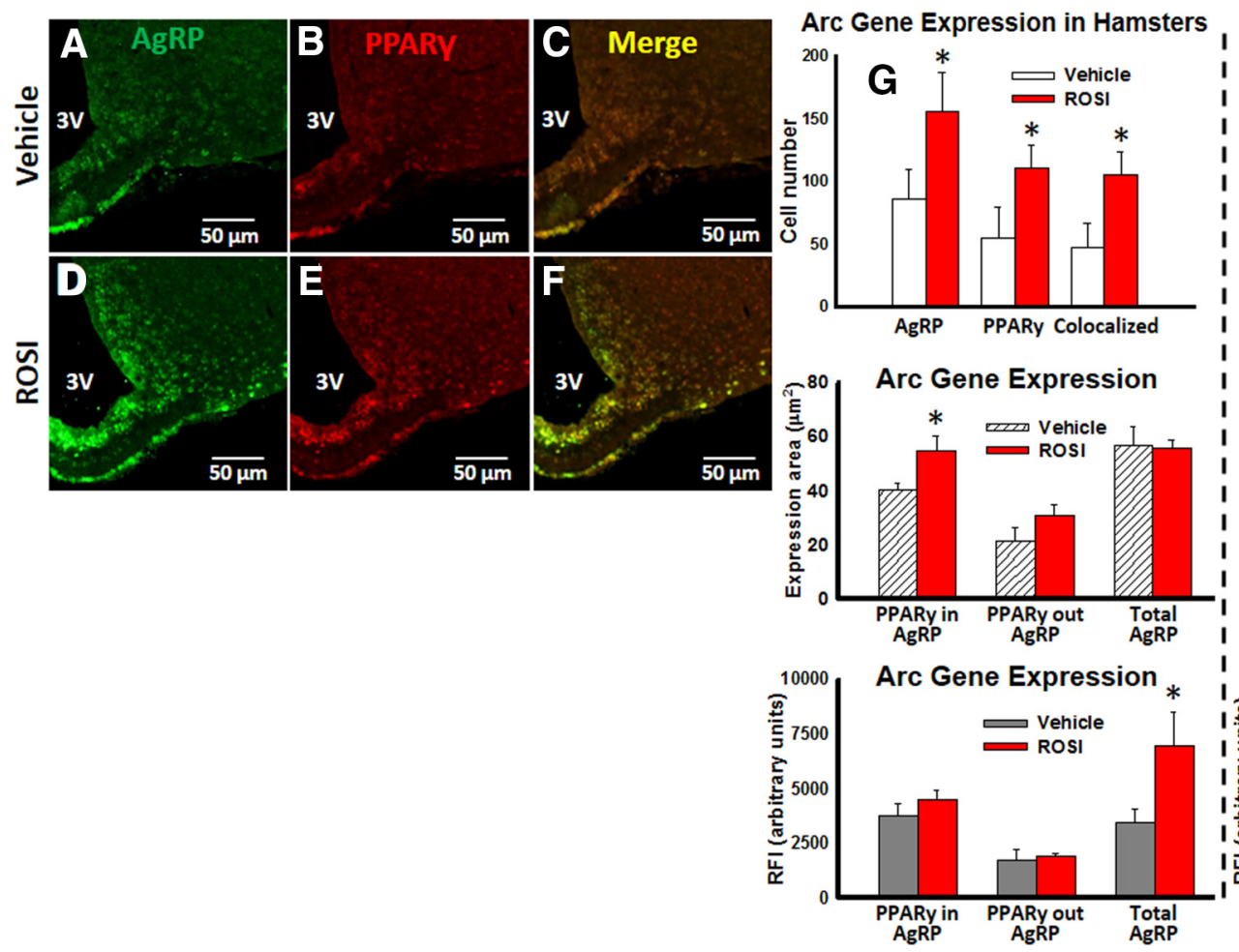

Figure 3. ROSI (intraperitoneal), a PPAR $\gamma$ agonist, increases $A g R P$ and $P P A R \gamma$ mRNA in the Arc. Double-fluorescent in situ hybridization for $A g R P$ (green), $P P A R \gamma$ (red), and merged representative images from hamsters injected with vehicle (A-C) or ROSI (D-F). G, Quantification of AgRP and PPAR $\gamma$ mRNA from hamsters injected with either vehicle or ROSI. AgRP and PPAR $\gamma$ mRNA expression represented as average number of cells (top), area of expression (middle), and RFI (bottom). $\boldsymbol{H}$, Quantification of Arc AgRPand PPAR y expression from C57BL/6 mouse brains after vehicle or ROSl injections expressed as average number of cells (top), area of expression (middle), and RFI (bottom). ${ }^{*} p<0.05$, different from vehicle-induced values. Dotted line separates hamster (G, $\left.n=10\right)$ from mouse $(\boldsymbol{H}, n=10)$ quantification. Error bars denote SEM.
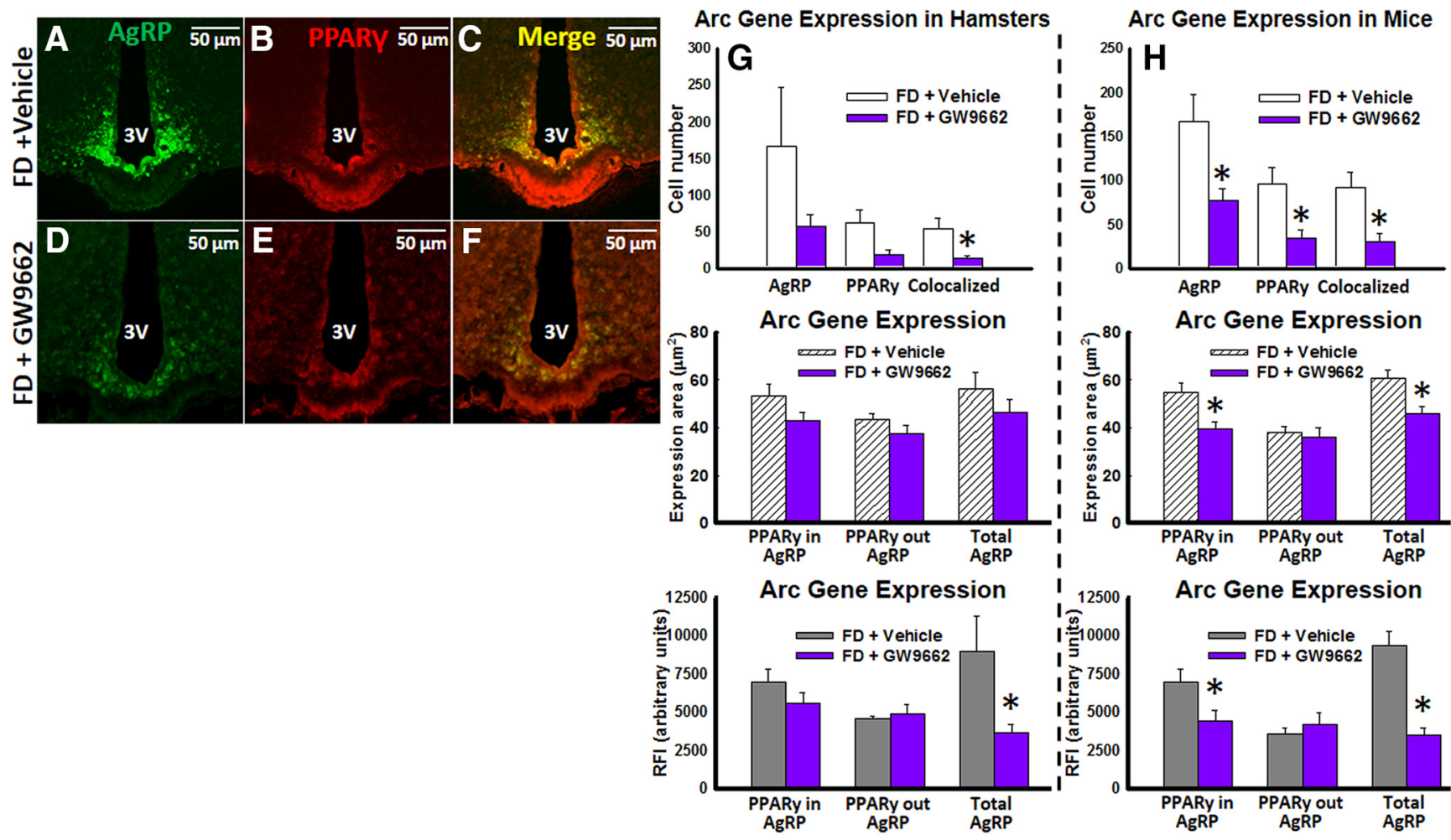

Figure 4. GW9662 (intraperitoneal), a PPAR $\gamma$ antagonist, blocks FD-induced increases in AgRP and PPAR $\gamma$ mRNA expression in the Arc. Double-fluorescent in situ hybridization for AgRP (green), $\operatorname{PPAR} \gamma$ (red), and merged representative images from C57BL/6 mice FD $24 \mathrm{~h}$ and injected with vehicle (A-C) or GW9662 (D-F). G, Quantification of Arc AgRP and PPAR $\gamma$ expression from $48 \mathrm{~h}$ FD hamsters injected with either vehicle or GW9662 represented as average number of cells (top), area of expression (middle), and RFI (bottom). $\boldsymbol{H}$, Quantification of Arc AgRP and PPAR $\gamma$ expression from $24 \mathrm{~h}$ FD mice injected with vehicle or GW9662 expressed as average number of cells (top), area of expression (middle), and RFI (bottom). ${ }^{*} p<0.05$, different from vehicle-induced values. Dotted line separates hamster $(\boldsymbol{G}, n=10)$ from mouse $(\boldsymbol{H}, n=10)$ quantification. Error bars denote SEM. 


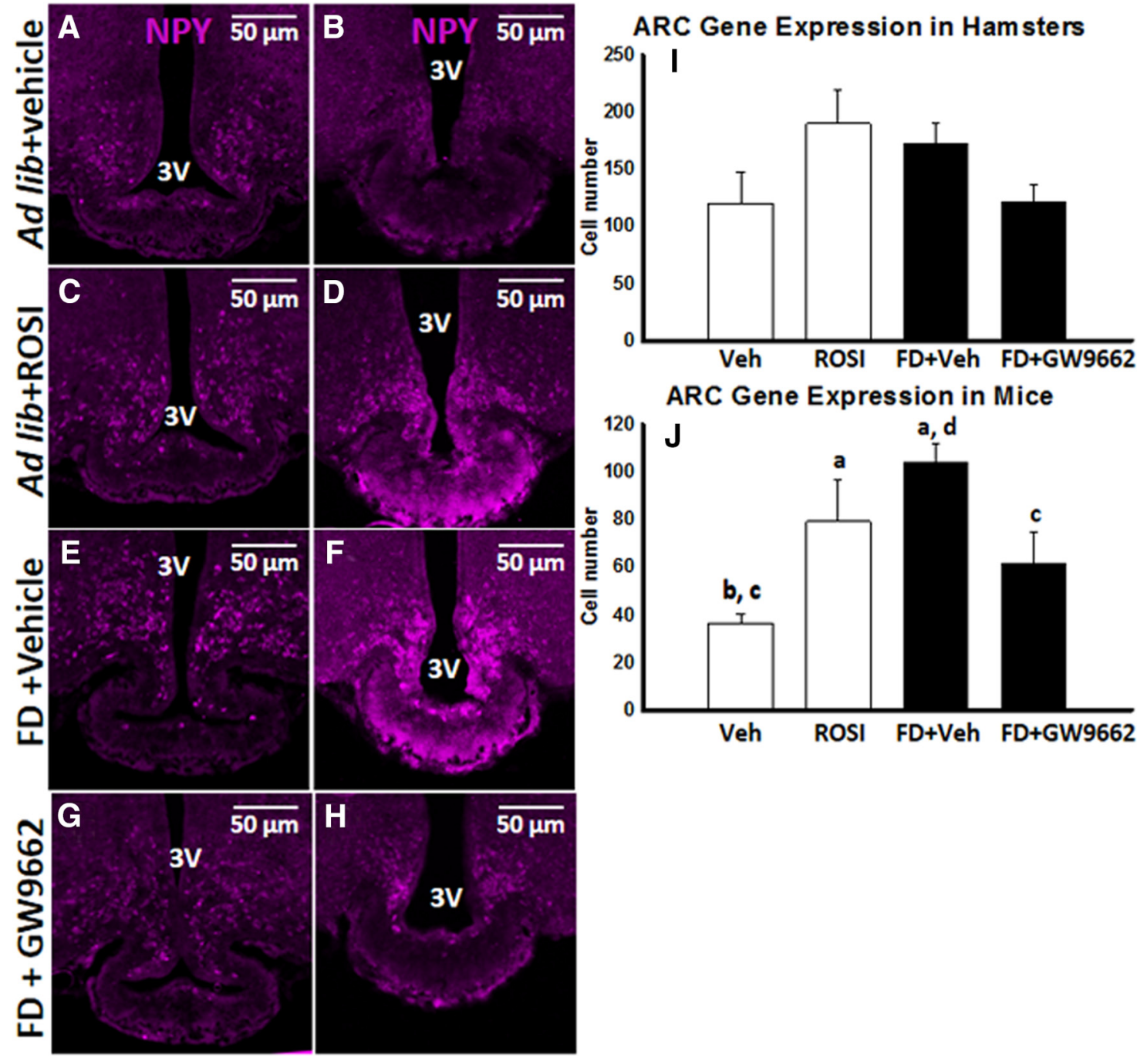

Figure 5. PPAR $\gamma$ is sufficient to induce and necessary for FD-induced NPY expression in the Arc. Representative images of single-fluorescent in situ hybridization for NPY from hamsters (left, $n=$ 10) and mice (right, $n=10$ ) fed ad libitum and injected with ROSI (intraperitoneal) or vehicle ( $\boldsymbol{A}-\boldsymbol{D})$ or FD and injected with GW9662 (intraperitoneal) or vehicle (Veh; $\boldsymbol{E}-\boldsymbol{H}$ ). Quantification of Arc $N P Y$ expression from hamsters $(\boldsymbol{I})$ and mice $(\boldsymbol{J})$ represented as average number of cells within the Arc. Bars are lettered a- $\mathrm{d}$ (left to right), and letters indicate significant differences from other treatments $(p<0.05)$. Error bars denote SEM.

hamsters (see Fig. 5I). Plasma acylated ghrelin was not significantly affected by ROSI in either species (see Fig. 6).

Peripheral GW9662 blocks FD-induced increases in Arc NPY, $A g R P, P P A R \gamma$, and $A g R P$ plus PPAR $\gamma$ mRNA in hamsters and mice but does not affect plasma ghrelin

Peripheral GW9662 blocked FD-induced increases in Arc NPY, $A g R P, P P A R \gamma$, and $A g R P$ plus PPAR $\gamma$ colocalized detectable cells in mice $\left(t_{(8)}=-2.797, p<0.05 ; t_{(8)}=-2.697, p<0.05 ; t_{(8)}=\right.$ $-3.114, p<0.05 ; t_{(8)}=-3.024, p<0.05$; Figs. $\left.4 H, 5 J\right)$, as well as the number of $A g R P$ plus $P P A R \gamma$ mRNA colocalized cells in hamsters $\left(t_{(8)}=-2.537, p<0.05\right.$; Fig. $\left.4 G\right)$. FD-induced increases in the area of mouse Arc $A g R P$ expression and RFI were markedly blocked by GW9662 $\left(t_{(8)}=-3.224, p<0.05 ; t_{(8)}=-5.473, p<\right.$ 0.01; Fig. $4 H$ ), as was PPAR $\gamma$ expression in AgRP/NPY neurons for both measures $\left(t_{(8)}=-3.302, p<0.05 ; t_{(8)}=-2.309, p<\right.$ 0.05; Fig. 4H). Hamster Arc AgRP mRNA RFI also was significantly decreased by GW9662 $\left(t_{(8)}=-2.321, p<0.05\right.$; Fig. $\left.4 G\right)$. Plasma acylated ghrelin was not significantly affected by GW9662 in either species (Fig. 6).

\section{Discussion}

Collectively, these experiments demonstrate that PPAR $\gamma$ is necessary for and sufficient to induce Arc AgRP mRNA, and to a lesser extent NPY mRNA, in Siberian hamsters and C57BL/6 mice through an apparent ghrelin-independent pathway. These findings highlight a possible mechanism by which AgRP/NPY neurons respond to FD, demonstrate a novel role of PPAR $\gamma$ for $A g R P$ and NPY expression in the brain, and fortify potential differences between Siberian hamster and mouse AgRP/NPY neuronal properties. That is, PPAR $\gamma$ activity may be required for FD-induced increased Arc AgRP mRNA and sufficient to induce $A g R P$ mRNA for both species, yet NPY appears less affected in Siberian hamsters. Given these data (Fig. 1) and the well demonstrated effect of AgRP/NPY on feeding (Dutia et al., 2013; Krashes et al., 2013, 2014), this suggests that PPAR $\gamma$ may be required for $\mathrm{FD} /$ food restriction-induced refeeding and could, for example, potentially be targeted therapeutically in humans suffering from failed dieting caused by food restriction-induced increases in appetite and illustrates a possible mechanism as to how humans taking TZDs gain body mass by overeating. 

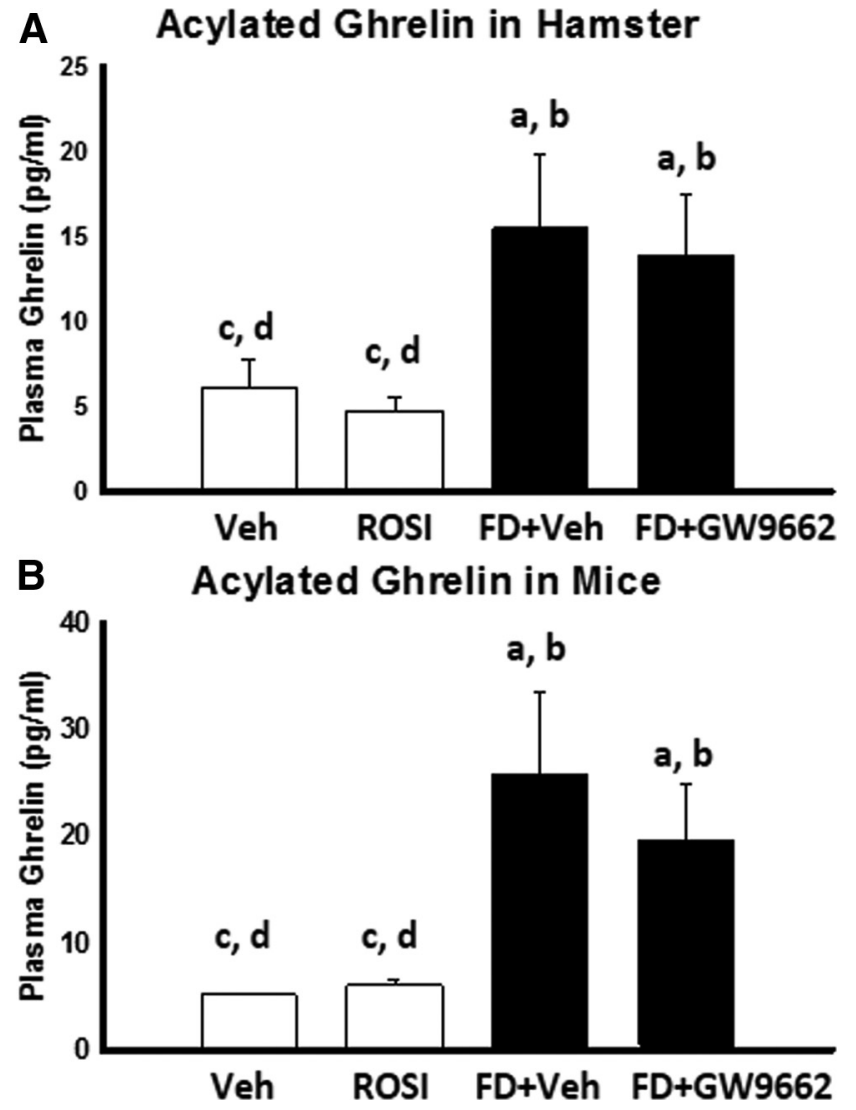

Figure 6. Plasma ghrelin is not affected by ROSI (intraperitoneal) or GW9662 (intraperitoneal). Acylated ghrelin measured from hamsters $(\boldsymbol{A}, n=10)$ and mice $(\boldsymbol{B}, n=10)$ fed ad libitum and treated with ROSI or vehicle (Veh) or FD and treated with GW9662 or vehicle. Bars are lettered $a-d$ (left to right), and letters indicate significant differences from other treatments $(p<0.05)$. Error bars denote SEM.

Hamsters and mice were both used in this study to compare PPAR $\gamma$ responses that affect feeding between dissimilar species: Siberian hamsters (hoard food naturally, thereby allowing study of an appetitive ingestive behavior relevant to humans; for review, see Bartness et al., 2011) and laboratory mice. Many rodent species overeat when refed after FD/diet restriction (Hollopeter et al., 1998; Naveilhan et al., 1999; Segal-Lieberman et al., 2003; Ste Marie et al., 2005). In contrast, both Siberian and Syrian hamsters (Simek, 1974; Silverman and Zucker, 1976; Rowland, 1984; Bartness and Clein, 1994; Bartness et al., 1995; Bartness, 1997) and also humans (Dodd et al., 1977; Hetherington et al., 2000; Levitsky and DeRosimo, 2010) do not markedly overeat after FD or fast. Instead, hamsters and humans increase appetitive ingestive behaviors, such as foraging/hoarding (for review, see Bartness et al., 2011). Hungry humans purchase more and higher-calorie foods than their sated counterparts, an effect exaggerated among people who are obese (Dodd et al., 1977; Beneke and Davis, 1985; Mela et al., 1996; Ransley et al., 2003). Thus, FD increased ingestive behaviors by Siberian hamsters with significant attenuation of food hoarding - and intake to a lesser extent-by PPAR $\gamma$ antagonism (Fig. 1), suggesting that appetitive ingestive behavior (food hoarding) may be targeted preferentially to intake because of the marked control and similarity to human appetitive feeding. These behavioral changes together with FDinduced PPAR $\gamma$ expression all indicate that PPAR $\gamma$ is involved with FD-induced responses across at least two rodent species.
Therefore, our data depict somewhat similar neural responses, with $N P Y$ marginally less sensitive to PPAR $\gamma$ manipulation in hamsters, and between hamsters and mice despite different behavioral responses to FD (for review, see Keen-Rhinehart et al., 2013).

PPAR $\gamma$ manipulations affect PPAR $\gamma$ within AgRP/NPY neurons in a feedforward manner. That is, as demonstrated by previous studies using PPAR $\gamma$ modulators (Dreyer et al., 1993; Chawla et al., 2001; Yi et al., 2008), PPAR $\gamma$ agonism increases and antagonism decreases PPAR $\gamma$ mRNA. Our results do not establish the cellular mechanisms of $P P A R \gamma$ regulation; rather, they reiterate the feedforward effects of peripheral manipulation of central PPAR $\gamma$ mRNA. In addition, FD increases PPAR $\gamma$ mRNA and its circulating ligands (Walker and Remley, 1970; Dreyer et al., 1993). Thus, PPAR $\gamma$ mRNA is naturally upregulated with increases in ligand availability as caused by FD.

In contrast, Sarruf et al. (2009) found that PPAR $\gamma$ mRNA does not change in the whole hypothalamus after FD in rats and mice. Although this careful study strengthened our understanding of the central role of PPAR $\gamma$ in feeding, it lacks cellular resolution to observe the effects reported here. One consolidated hypothesis is that PPAR $y$ expression may decrease elsewhere in the hypothalamus, thus masking any increases in AgRP/NPY neurons within whole-hypothalamus analysis. If PPAR $\gamma$ activation is necessary for FD-induced increases in Arc AgRP and NPY expression and, thus, feeding, then this guides us to other possible roles for PPAR $\gamma$ in nonArc hypothalamic structures in which it is also expressed (e.g., lateral, paraventricular, and dorsomedial hypothalamus; Sarruf et al., 2009) and perhaps may serve a role in other responses to FD and/or other non-ingestive behaviors. Our data do not characterize or, more importantly, discount the metabolic role of PPAR $\gamma$ in non-Arc and especially non-hypothalamic structures. Given its sensitivity to circulating metabolic fuels (Dreyer et al., 1993) and its response here to FD, PPAR $\gamma$ activity likely extends to many neural structures involved in the central control of peripheral metabolism.

Of clinical interest, PPAR $\gamma$ is targeted pharmacologically in humans by insulin-sensitizing drugs, TZDs, to combat type II diabetes. Albeit effective at improving insulin sensitivity (Gerstein et al., 2006), two key side-effects of chronic TZD treatment are increases in subcutaneous white adipose tissue, likely linked to the known role of PPAR $\gamma$ in adipocyte differentiation (Rosen et al., 1999), and increases in food intake (Fonseca, 2003). Our data, and those of others (Lehrke and Lazar, 2005), indicate a mechanism whereby TZDs may enhance caloric intake/storage that in surfeit could be deposited as lipid in subcutaneous fat. We note that one of us reported limited access to the brain by radioactively labeled ROSI injected intravenously in rats (Festuccia et al., 2008), and we are now at a loss to explain those results because it is clear that peripheral ROSI affects ad libitum and FD-induced behavior and brain function (Nicolakakis and Hamel, 2011) clearly showing CNS action (Higgins and Depaoli, 2010). Because PPAR $\gamma$ has been shown only recently to affect feeding, TZD-induced fat deposition has been attributed to subcutaneous fat lipogenesis (Bentley, 1989) and sympathetic nervous system control (Festuccia et al., 2008). The effects on ingestive behavior witnessed here and by others (Ryan et al., 2011) shift the proverbial tide to implicate PPAR $\gamma$ activity in a broader sense to generate positive energy balance simultaneously through multiple mechanisms (e.g., increases in foraging/hoarding, food intake, and adipogenesis), including decreasing energy expenditure in addition to lipogenesis. 
Circulating ghrelin also was measured here because it is possible that peripheral $\operatorname{PPAR} \gamma$ modulation affects plasma ghrelin, as does FD (Ariyasu et al., 2001; Toshinai et al., 2001; Bagnasco et al., 2002), which can directly stimulate AgRP/NPY neurons in the Arc through GHSR-1a. Human patients taking ROSI have higher plasma ghrelin compared with control subjects; in contrast, fasted human ghrelin concentrations are reduced by TZDs (Kadoglou et al., 2010). Thus, the relation between PPAR $\gamma$ manipulation and plasma ghrelin was unclear. We have demonstrated here that ad libitum-fed mice and hamsters with ROSI treatments and FD mice and hamsters with GW9662 treatments do not have perturbed active plasma ghrelin. Thus, if TZDs do not affect ghrelin levels during FD, then PPAR $\gamma$ action must affect $A g R P$ and NPY gene expression through a ghrelin-independent pathway, as would be inferred from human data and our findings here. In addition, central ROSI increases ingestive behaviors seen here and by others (Ryan et al., 2011), further supporting that a central ghrelin-independent PPAR $\gamma$ mechanism exists. In support of this, FD Zucker fatty rats given TZDs have lower plasma ghrelin than controls yet eat more food and gain more fat mass after refeeding (Saitoh et al., 2007). Collectively, these data clarify that ROSI-induced and GW9662-attenuating effects on $A g R P$ and NPY mRNA are not dependent on ghrelin.

Despite the exclusion of ghrelin here, how FD induces PPAR $\gamma$ expression and consequently $A g R P$ and $N P Y$ is not known precisely, but our data help to solve this mystery in that antagonism of PPAR $\gamma$ blocks $A g R P$ and NPY expression normally increased with FD in laboratory mice and Siberian hamsters. This does not indicate that PPAR $\gamma$ is the only or overriding signal through which the brain responds to FD. Indeed, ingestive behaviors are governed by redundant distributed systems (for review, see Grill and Kaplan, 2001; Grill, 2006; Grill and Hayes, 2012), and, therefore, it should not be concluded from the present data that only the Arc and/or Arc AgRP/NPY are involved in ingestive behavioral responses to FD. However, it is tempting to speculate that AgRP/NPY neurons in the Arc may require PPAR $\gamma$ ligands (for example, available circulating fatty acids) to initiate and maintain persistent refeeding after FD in rats and mice and food hoarding in hamsters and humans.

Our experiments here provide several novel findings: (1) central and peripheral PPAR $\gamma$ activation triggered increaseswhereas peripheral PPAR $\gamma$ antagonism attenuated FDinduced increases-in food hoarding and intake by Siberian hamsters (a rarely studied yet meaningful parallel to human ingestive behavior); (2) FD induced increases in PPAR $\gamma$, specifically within AgRP/NPY neurons in the Arc; (3) PPAR $\gamma$ activation is sufficient and necessary for FD-induced increases in Arc AgRP and NPY expression; and (4) PPAR $\gamma$ treatment does not affect acylated ghrelin $\gamma$. This examination of a rarely studied ingestive behavior (food hoarding), evidence of a much-studied metabolic nuclear receptor responding acutely to FD (PPAR $\gamma$ ), and the control of FD-induced $A g R P$ and $N P Y$ expression by PPAR $\gamma$ adds new mechanisms that control feeding and/or the response to FD. Therefore, the present data deepen our understanding of a major control of ingestive behavior, a period without food, for two rodent species with possible inference to humans.

\section{References}

Andreasson A, Kiss NB, Juhlin CC, Höög A (2013) Long-term storage of endocrine tissues at $-80^{\circ} \mathrm{C}$ does not adversely affect RNA quality or overall histomorphology. Biopreserv Biobank 11:366-370. CrossRef Medline
Ariyasu H, Takaya K, Tagami T, Ogawa Y, Hosoda K, Akamizu T, Suda M, Koh T, Natsui K, Toyooka S, Shirakami G, Usui T, Shimatsu A, Doi K, Hosoda H, Kojima M, Kangawa K, Nakao K (2001) Stomach is a major source of circulating ghrelin, and feeding state determines plasma ghrelin-like immunoreactivity levels in humans. J Clin Endocrinol Metab 86:4753-4758. CrossRef Medline

Bagnasco M, Kalra PS, Kalra SP (2002) Ghrelin and leptin pulse discharge in fed and fasted rats. Endocrinology 143:726-729. CrossRef Medline

Bartness TJ (1997) Food hoarding is increased by pregnancy, lactation and food deprivation in Siberian hamsters. Am J Physiol 272:R118-R125. Medline

Bartness TJ, Clein MR (1994) Effects of food deprivation and restriction, and metabolic blockers on food hoarding in Siberian hamsters. Am J Physiol 266:R1111-R1117. Medline

Bartness TJ, Morley JE, Levine AS (1995) Effects of food deprivation and metabolic fuel utilization on the photoperiodic control of food intake in Siberian hamsters. Physiol Behav 57:61-68. CrossRef Medline

Bartness TJ, Keen-Rhinehart E, Dailey MJ, Teubner BJ (2011) Neural and hormonal control of food hoarding. Am J Physiol 301:R641-R655. CrossRef Medline

Beneke WM, Davis CH (1985) Relationship of hunger, use of a shopping list and obesity to food purchases. Int J Obes 9:391-399. Medline

Bentley DW (1989) Current challenges and future opportunities. Infect Control Hosp Epidemiol 10:481-483. Medline

Bowers RR, Festuccia WTL, Song CK, Shi H, Migliorini RH, Bartness TJ (2004) Sympathetic innervation of white adipose tissue and its regulation of fat cell number. Am J Physiol Regul Integr Comp Physiol 286:R1167R1175. Medline

Brady LS, Smith MA, Gold PW, Herkenham M (1990) Altered expression of hypothalamic neuropeptide mRNAs in food-restricted and fooddeprived rats. Neuroendocrinology 52:441-447. CrossRef Medline

Chawla A, Repa JJ, Evans RM, Mangelsdorf DJ (2001) Nuclear receptors and lipid physiology: opening the X-files. Science 294:1866-1870. CrossRef Medline

Cheung CC, Clifton DK, Steiner RA (1997) Proopiomelanocortin neurons are direct targets for leptin in the hypothalamus. Endocrinology 138: 4489-4492. CrossRef Medline

Clark JT, Kalra PS, Kalra SP (1985) Neuropeptide Y stimulates feeding but inhibits sexual behavior in rats. Endocrinology 117:2435-2442. CrossRef Medline

Cowley MA, Pronchuk N, Fan W, Dinulescu DM, Colmers WF, Cone RD (1999) Integration of NPY, AGRP, and melanocortin signals in the hypothalamic paraventricular nucleus: evidence of a cellular basis for the adipostat. Neuron 24:155-163. CrossRef Medline

Day DE, Bartness TJ (2001) Effects of foraging effort on body fat and food hoarding by Siberian hamsters. J Exp Zool 289:162-171. CrossRef Medline

Day DE, Bartness TJ (2004) Agouti-related protein increases food hoarding, but not food intake by Siberian hamsters. Am J Physiol Regul Integr Comp Physiol 286:R38-R45. Medline

Day DE, Keen-Rhinehart E, Bartness TJ (2005) Role of NPY and its receptor subtypes in foraging, food hoarding, and food intake by Siberian hamsters. Am J Physiol Regul Integr Comp Physiol 289:R29-R36. CrossRef Medline

Diano S, Liu ZW, Jeong JK, Dietrich MO, Ruan HB, Kim E, Suyama S, Kelly K, Gyengesi E, Arbiser JL, Belsham DD, Sarruf DA, Schwartz MW, Bennett AM, Shanabrough M, Mobbs CV, Yang X, Gao XB, Horvath TL (2011) Peroxisome proliferation-associated control of reactive oxygen species sets melanocortin tone and feeding in diet-induced obesity. Nat Med 17:1121-1127. CrossRef Medline

Dodd DK, Stalling RB, Bedell J (1977) Grocery purchases as a function of obesity and assumed food deprivation. Int J Obes 1:43-47. Medline

DREAM (Diabetes REduction Assessment with ramipril and rosiglitazone Medication) Trial Investigators, Gerstein HC, Yusuf S, Bosch J, Pogue J, Sheridan P, Dinccag N, Hanefeld M, Hoogwerf B, Laakso M, Mohan V, Shaw J, Zinman B, Holman RR (2006) Effect of rosiglitazone on the frequency of diabetes in patients with impaired glucose tolerance or impaired fasting glucose: a randomised controlled trial. Lancet 368:10961105. CrossRef Medline

Dreyer C, Keller H, Mahfoudi A, Laudet V, Krey G, Wahli W (1993) Positive regulation of the peroxisomal beta-oxidation pathway by fatty acids 
through activation of peroxisome proliferator-activated receptors (PPAR). Biol Cell 77:67-76. CrossRef Medline

Dutia R, Kim AJ, Modes M, Rothlein R, Shen JM, Tian YE, Ihbais J, Victory SF, Valcarce C, Wardlaw SL (2013) Effects of AgRP inhibition on energy balance and metabolism in rodent models. PLoS One 8:e65317. CrossRef Medline

Festuccia WT, Oztezcan S, Laplante M, Berthiaume M, Michel C, Dohgu S, Denis RG, Brito MN, Brito NA, Miller DS, Banks WA, Bartness TJ, Richard D, Deshaies Y (2008) Peroxisome proliferator- $\gamma$-activated receptormediated positive energy balance in the rat is associated with reduced sympathetic drive to adipose tissues and thyroid status. Endocrinology 149:2121-2130. CrossRef Medline

Fonseca V (2003) Effect of thiazolidinediones on body weight in patients with diabetes mellitus. Am J Med 115 [Suppl 8A]:42S-48S.

Grill HJ (2006) Distributed neural control of energy balance: contributions from hindbrain and hypothalamus. Obesity (Silver Spring) 14 [Suppl 5]:216S-221S.

Grill HJ, Hayes MR (2012) Hindbrain neurons as an essential hub in the neuroanatomically distributed control of energy balance. Cell Metab 16: 296-309. CrossRef Medline

Grill HJ, Kaplan JM (2001) Interoceptive and integrative contributions of forebrain and brainstem to energy balance control. Int J Obes Relat Metab Disord 25 [Suppl 5]:S73-S77.

Hahn TM, Breininger JF, Baskin DG, Schwartz MW (1998) Coexpression of Agrp and NPY in fasting-activated hypothalamic neurons. Nat Neurosci 1:271-272. CrossRef Medline

Hetherington MM, Stoner SA, Andersen AE, Rolls BJ (2000) Effects of acute food deprivation on eating behavior in eating disorders. Int J Eat Disord 28:272-283. CrossRef Medline

Higgins LS, Depaoli AM (2010) Selective peroxisome proliferator-activated receptor gamma (PPARgamma) modulation as a strategy for safer therapeutic PPARgamma activation. Am J Clin Nutr 91:267S-272S. CrossRef Medline

Hollopeter G, Erickson JC, Seeley RJ, Marsh DJ, Palmiter RD (1998) Response of neuropeptide Y-deficient mice to feeding effectors. Regul Pept 75-76:383-389.

Issemann I, Green S (1990) Activation of a member of the steroid hormone receptor superfamily by peroxisome proliferators. Nature 347:645-650. CrossRef Medline

Jensen TL, Kiersgaard MK, Sørensen DB, Mikkelsen LF (2013) Fasting of mice: a review. Lab Anim 47:225-240. CrossRef Medline

Kadoglou NP, Tsanikidis H, Kapelouzou A, Vrabas I, Vitta I, Karayannacos PE, Liapis CD, Sailer N (2010) Effects of rosiglitazone and metformin treatment on apelin, visfatin, and ghrelin levels in patients with type 2 diabetes mellitus. Metabolism 59:373-379. CrossRef Medline

Keen-Rhinehart E, Ondek K, Schneider JE (2013) Neuroendocrine regulation of appetitive ingestive behavior. Front Neurosci 7:213. CrossRef Medline

Krashes MJ, Koda S, Ye C, Rogan SC, Adams AC, Cusher DS, Maratos-Flier E, Roth BL, Lowell BB (2011) Rapid, reversible activation of AgRP neurons drives feeding behavior in mice. J Clin Invest 121:1424-1428. CrossRef Medline

Krashes MJ, Shah BP, Koda S, Lowell BB (2013) Rapid versus delayed stimulation of feeding by the endogenously released AgRP neuron mediators GABA, NPY, and AgRP. Cell Metab 18:588-595. CrossRef Medline

Krashes MJ, Shah BP, Madara JC, Olson DP, Strochlic DE, Garfield AS, Vong L, Pei H, Watabe-Uchida M, Uchida N, Liberles SD, Lowell BB (2014) An excitatory paraventricular nucleus to AgRP neuron circuit that drives hunger. Nature 507:238-242. CrossRef Medline

Lehrke M, Lazar MA (2005) The many faces of PPARgamma. Cell 123:993999. CrossRef Medline

Lein ES, Hawrylycz MJ, Ao N, Ayres M, Bensinger A, Bernard A, Boe AF, Boguski MS, Brockway KS, Byrnes EJ, Chen L, Chen L, Chen TM, Chin MC, Chong J, Crook BE, Czaplinska A, Dang CN, Datta S, Dee NR, et al. (2007) Genome-wide atlas of gene expression in the adult mouse brain. Nature 445:168-176. CrossRef Medline

Levitsky DA, DeRosimo L (2010) One day of food restriction does not result in an increase in subsequent daily food intake in humans. Physiol Behav 99:495-499. CrossRef Medline

Li JY, Finniss S, Yang YK, Zeng Q, Qu SY, Barsh G, Dickinson C, Gantz I (2000) Agouti-related protein-like immunoreactivity: characterization of release from hypothalamic tissue and presence in serum. Endocrinology 141:1942-1950. CrossRef Medline

Mayerson AB, Hundal RS, Dufour S, Lebon V, Befroy D, Cline GW, Enocksson S, Inzucchi SE, Shulman GI, Petersen KF (2002) The effects of rosiglitazone on insulin sensitivity, lipolysis, and hepatic and skeletal muscle triglyceride content in patients with type 2 diabetes. Diabetes 51:797-802. CrossRef Medline

Mela DJ, Aaron JI, Gatenby SJ (1996) Relationships of consumer characteristics and food deprivation to food purchasing behavior. Physiol Behav 60:1331-1335. CrossRef Medline

Naveilhan P, Hassani H, Canals JM, Ekstrand AJ, Larefalk A, Chhajlani V, Arenas E, Gedda K, Svensson L, Thoren P, Ernfors P (1999) Normal feeding behavior, body weight and leptin response require the neuropeptide Y Y2 receptor. Nat Med 5:1188-1193. CrossRef Medline

Nicolakakis N, Hamel E (2011) Neurovascular function in Alzheimer's disease patients and experimental models. J Cereb Blood Flow Metab 31: 1354-1370. CrossRef Medline

Ollmann MM, Wilson BD, Yang YK, Kerns JA, Chen Y, Gantz I, Barsh GS (1997) Antagonism of central melanocortin receptors in vitro and in vivo by agouti-related protein. Science 278:135-138. CrossRef Medline

Paxinos G, Franklin KBJ (2007) The mouse brain in stereotaxic coordinates, Ed 2. New York: Academic.

Ransley JK, Donnelly JK, Botham H, Khara TN, Greenwood DC, Cade JE (2003) Use of supermarket receipts to estimate energy and fat content of food purchased by lean and overweight families. Appetite 41:141-148. CrossRef Medline

Rosen ED, Sarraf P, Troy AE, Bradwin G, Moore K, Milstone DS, Spiegelman BM, Mortensen RM (1999) PPAR gamma is required for the differentiation of adipose tissue in vivo and in vitro. Mol Cell 4:611-617. CrossRef Medline

Rowland N (1984) Metabolic fuel homeostasis in golden hamsters: effects of fasting, refeeding, glucose, and insulin. Am J Physiol 247:R57-R62. Medline

Ryan KK, Li B, Grayson BE, Matter EK, Woods SC, Seeley RJ (2011) A role for central nervous system PPAR-gamma in the regulation of energy balance. Nat Med 17:623-626. CrossRef Medline

Saitoh Y, Liu R, Ueno H, Mizuta M, Nakazato M (2007) Oral pioglitazone administration increases food intake through ghrelin-independent pathway in Zucker fatty rat. Diabetes Res Clin Pract 77:351-356. CrossRef Medline

Sarruf DA, Yu F, Nguyen HT, Williams DL, Printz RL, Niswender KD, Schwartz MW (2009) Expression of peroxisome proliferatoractivated receptor-gamma in key neuronal subsets regulating glucose metabolism and energy homeostasis. Endocrinology 150:707-712. CrossRef Medline

Schneider CA, Rasband WS, Eliceiri KW (2012) NIH Image to ImageJ: 25 years of image analysis. Nat Methods 9:671-675. CrossRef Medline

Segal-Lieberman G, Trombly DJ, Juthani V, Wang X, Maratos-Flier E (2003) NPY ablation in C57BL/6 mice leads to mild obesity and to an impaired refeeding response to fasting. Am J Physiol Endocrinol Metab 284:E1131E1139. Medline

Silverman HJ, Zucker I (1976) Absence of post-fast food compensation in the golden hamster (Mesocricetus auratus). Physiol Behav 17:271-285. CrossRef Medline

Simek V (1974) Energy metabolism of golden hamsters adapted to intermittent fasting: influence of season and sex. Physiol Bohemoslov 23:437-446. Medline

Ste Marie L, Luquet S, Cole TB, Palmiter RD (2005) Modulation of neuropeptide $\mathrm{Y}$ expression in adult mice does not affect feeding. Proc Natl Acad Sci U S A 102:18632-18637. CrossRef Medline

Teubner BJ, Keen-Rhinehart E, Bartness TJ (2012) Third ventricular coinjection of subthreshold doses of NPY and AgRP stimulate food hoarding and intake and neural activation. Am J Physiol Regul Integr Comp Physiol 302:R37-R48. CrossRef Medline

Toshinai K, Mondal MS, Nakazato M, Date Y, Murakami N, Kojima M, Kangawa K, Matsukura S (2001) Upregulation of ghrelin expression in the stomach upon fasting, insulin- induced hypoglycemia, and leptin administration. Biochem Biophys Res Commun 281:1220-1225. CrossRef Medline

van der Laan S, Lachize SB, Schouten TG, Vreugdenhil E, de Kloet ER, Meijer OC (2005) Neuroanatomical distribution and colocalisation of nuclear receptor corepressor $(\mathrm{N}-\mathrm{CoR})$ and silencing mediator of 
retinoid and thyroid receptors (SMRT) in rat brain. Brain Res 1059: 113-121. CrossRef Medline

Vazdarjanova A, McNaughton BL, Barnes CA, Worley PF, Guzowski JF (2002) Experience-dependent coincident expression of the effector immediate-early genes arc and Homer la in hippocampal and neocortical neuronal networks. J Neurosci 22:10067-10071. Medline

Walker DW, Remley NR (1970) The relationships among percentage body weight loss, circulating free fatty acids and consummatory behavior in rats. Physiol Behav 5:301-309. CrossRef Medline

Wang Q, Dryden S, Frankish HM, Bing C, Pickavance L, Hopkins D, Buckingham R, Williams G (1997) Increased feeding in fatty Zucker rats by the thiazolidinedione BRL 49653 (rosiglitazone) and the possible involve- ment of leptin and hypothalamic neuropeptide Y. Br J Pharmacol 122: 1405-1410. CrossRef Medline

Weiner J (1987) Limits to energy budget and tactics in energy investments during reproduction in the Djungarian hamster (Phodopus sungorus sungorus Pallas 1770). Symp Zool Soc Lond 57:167-187.

Wu Q, Boyle MP, Palmiter RD (2009) Loss of GABAergic signaling by AgRP neurons to the parabrachial nucleus leads to starvation. Cell 137:12251234. CrossRef Medline

Yi JH, Park SW, Brooks N, Lang BT, Vemuganti R (2008) PPARgamma agonist rosiglitazone is neuroprotective after traumatic brain injury via anti-inflammatory and anti-oxidative mechanisms. Brain Res 1244:164172. CrossRef Medline 